\title{
Development of Psychosocial Telenursing Education Stigma of Suspected Covid-19 (Rapid Reactive) Patients
}

\author{
Tri Wahyuni ${ }^{1}$, Parliani ${ }^{2}$, Kharisma Pratama ${ }^{3}$, Tutur Kardiatun ${ }^{4}$, Nita Zulfia $^{5}$, Paudilah ${ }^{6}$, \\ Gmeliana Adha Sari ${ }^{7}$ \\ 1,2,5,4,5,6,7Sekolah Tinggi Ilmu Keperawatan Muhammadiyah Pontianak \\ Email: tri@stikmuhptk.ac.id
}

\begin{abstract}
:
In the midst of the Covid-19 pandemic, there is one social phenomenon that has the potential to aggravate the situation, namely stigma in patients suspected of Covid-19 or rapid reactive results. The lab results have not actually confirmed that the patient is positive for Covid-19 but the social environment or negative associations of a person or group of people who experience symptoms or bear certain diseases result in stigma against a person. This study aims to find out how the experience and stigma in patients suspected of Covid - 19. This study uses qualitative approach method of phenomenological studies and in-depth interviews with telenursing. The number of participants in this study was 10 participants. This study obtained 5 themes, namely physiological experience, psychological experience, biological experience, sociological experience and spiritual experience. The high positive number of Covid-19 in Indonesia makes the emergence of negative stigma of society to patients exposed to Covid-19, not even just Patients who are positive of Covid-19 who get negative stigma, therefore for diagnostic enforcement it takes examination by Molecular Test: Real Time PCR (Polymerase Chain Reaction) method. The sample types used are bronchoalveolar lavage, nasopharyngeal or oropharyngeal swabs, sputum, tracheal aspirate, nasopharyngeal aspirate or nasal wash, and biopsy tissue including from the lungs. Real Time PCR check method is the golden standard for the enforcement of diagnostic Covid - 19.
\end{abstract}

Keywords:

stigma of suspected Covid - 19; telenursing; rapid reactive patients

\section{Introduction}

Coronavirus is a large family of viruses that can cause disease in animals or humans. In humans corona is known to cause respiratory infections ranging from the common cold to more severe diseases such as Middle East Respiratory Syndrome (MERS), and Severe Acute Respiratory Syndrome (SARS). According to who, coronavirus Covid-19 spreads people to people through small droplets from the nose or mouth that spread when a person coughs or exhales. These droplets then fall onto objects touched by others. Corona virus or Covid-19 originating from Wuhan, China because virus cells are able to produce similar viral cells to infect healthy cells in the body up to millions of cells in 10 days (WHO, 2020).

Currently there are as many as 65 countries infected with coronavirus. According to WHO data, Covid-19 cases from 03 January 2020 to 01 December 2020 recorded 63,136,866 confirmed cases of Covid-19 with a death rate of 1,469,402 (WHO, 2020).

Based on the Ministry of Health of the Republic of Indonesia, the first confirmed cases of Covid-19 on March 2, 2020 until December 2, 2020 were recorded confirmed Covid19 as many as 549,508 positive patients, with a record recovery of 458,880 and who died as many as 17,199 (Ministry of Health, 2020). 
Based on the West Kalimantan Provincial Health Office confirmed cases of Covid-19 from March 15, 2020 to December 2, 2020 recorded cases of Covid-19 5,092 positive, 2042 cured, 22 died (DinKes Prov. Kalbar, 2020). Based on the Kubu Raya District Health Office, Covid-19 confirmed cases recorded 334 positive cases, 236 cured, and 2 who died. While Sungai Ambawang District recorded 34 positive cases, 24 recovered, 0 died. Among them, Sungai Ambawang 27 positive, 20 cured, 0 died, Parit Timur 2 positive cases, 1 cured, 0 died, Lingga 5 positive cases, 3 cured, 0 died (DinKes KKR, 2020). The results show that the COVID-19 insecurity effects are more pronounced in upper-middle-income than in developing countries (Wijaya, 2021). Since the outbreak of the corona virus that was recorded starting at the end of 2019 in China, precisely the city of Wuhan, then later this virus became global and infected almost all countries in the world including Indonesia (Ningrum, 2020).

Efforts to help the government and health authorities analyze their patients, and then there are at least 4 mentions of people related to Covid-19, namely: People in Monitoring (ODP), Patients under Surveillance (PDP) or suspek, People without Symptoms (OTG), and positive Covid-19. Good news or information, being one of the supporting factors of recovery. If there is a positive do not be stigmatised, if necessary help if there is ODP in our region, which should be self-quarantine, must support each other for the sake of recovery (Ministry of Health, 2020).

One of the technologies that can be used to do monitoring by using telephone media is known as telehealth or telenursing. Telenursing can be interpreted as the use of information technology in the field of nursing to provide health services in the form of information or monitoring, where there is a long physical distance between nurses and clients (Triwibowo, 2013; Nurhidayah 2010). Based on the results of the study, it is known that the maximum control of treatment is done by using telenursing. Tools or media used in this telenursing one of them is Mobile. Mobile phone is a communication tool that is used either directly or indirectly, for example in the form of Short Message Service (SMS). SMS is the ability to send and receive messages in the form of text from and to mobile phones. The text sent can consist of words or numbers or alphanumeric combinations (Muharyani, 2011).

Telenursing is an easy path to access through today's information technology about nursing services through telenursing to be more effective and efficient. So that the quality of professional health services can be felt by the community. However, telenursing also has obstacles or weaknesses, especially if the network used is experiencing problems, will have an impact on sending and receiving messages. While another drawback of this telenursing is the possibility of technological failure such as internet connection interruption or disconnection of communication due to weather disruptions and so on so as to interfere with ongoing service activities, it also increases the risk to the security and confidentiality of client documents. The principle in providing nursing care is one of which is effectiveness and efficiency so that the purpose of service can be achieved. Currently there has been a lot of research that supports that telenursing innovation has a huge impact positif for nursingservices (Triwibowo, 2013). Telenursing method becomes an effective method in conducting in-depth interviews on research in the pandemic.

As a new disease, much is not yet known about the Covid-19 pandemic. Moreover, humans tend to be afraid of something unknown and it is easier to connect fear to "different groups". This is what causes the emergence of social stigma and discrimination against certain ethnicities as well as people who are considered to have a connection to this virus. We should also not stigmatize the families of patients who are detected reactive from rapid results, the impact ofsuch stigma makes patients become embarrassed, minder, setodecrease self-esteem. 
Self-esteem is self-achievement assessment by analyzing how far the behavior with the ideal self (Yanti, 2020). Low self-esteem is a feeling of worthless, meaningless and prolonged inferiority due to negative evaluation of oneself and self-ability (Keliat, et al., 2012). Situational low self-esteem is the emergence of negative perceptions of self-meaning in response to the current situation (Hanifah, 2020).

\section{Research Methods}

Many communities or environments that isolate or stigmatize one of its citizens are detected reactive from rapid results, when the word reactive does not necessarily indicate that it is positive Covid-19. Families of victims who are indicated reactive will also feel embarrassed, anxious, to lock themselves up because of the stigma by the surrounding residents can even be expelled for fear of spreading to other citizens. Therefore, the author is interested in developing psychosocial telenursing education against the stigma of patients suspected of Covid-19 (Rapid Reactive). This research aims: To identify the development of psychosocial telenursing education against the stigma of suspected Covid-19 (Rapid Reactive) patients. Research Method: Research using Qualitative Phenology Study with telenursing method interview. Discussion: In the midst of the Covid-19 outbreak, there is a social phenomenon that has the potential to aggravate the situation, namely social stigma or negative associations against a person or group of people who experience symptoms or bear certain diseases. They are labeled, stereotyped, discriminated against, treated differently, and subjected to status abuse due to association with a disease. Coronavirus is believed to cause $15-30 \%$ of all flu in adults and children. Coronavirus causes flu with major symptoms such as fever and sore throat due to adenoid swelling, especially in winter and early spring. Coronavirus can cause pneumonia, either direct viral pneumonia or secondary bacterial pneumonia, and can cause bronchitis, either direct viral bronchitis or secondary bacterial bronchitis. A human coronavirus discovered in 2003, SARS-CoV, which causes severe acute respiratory syndrome (SARS), has a unique pathogenesis because it causes infections of the upper and lower respiratory tracts.

\section{Discussion}

As a new disease, much is not yet known about the Covid-19 pandemic. Moreover, humans tend to be afraid of something unknown and it is easier to connect fear. This is what causes the emergence of social stigma and discrimination against certain ethnicities as well as people who are considered to have a connection to this virus. The feelings of confusion, anxiety, and fear that we feel can be understood, but that does not mean we can be prejudiced in sufferers, nurses, families, or those who are not sick but have symptoms similar to Covid19. If maintained in society, social stigma can make people hide their pain from being discriminated against, prevent them from seeking immediate health help, and prevent them from living healthy behaviors.

Based on the above phenomenon about stigma, researchers conducted interviews with telenursing methods via whattapp in depth to 10 respondents who had conducted rapid tests with reactive results and then obtained the results of research on 5 themes, namely physiological experience, psychological experience and spriritual experience of daily activities.

Physiological Experience: the patient said to experience in the house there is a family of fever, flu, cough (symptoms similar to Covid-19), patients sleep late at night and the next day go out of town and have rapid tests and the results are not suspected (reactive), and there are also patients with OTG (people without symptoms). Biological Experience: the patient 
said after knowing the reactive results then do a routine of sunbathing in the morning 10-15 minutes, consume vitamin $\mathrm{C}$, self-isolation, and set the menu of foods with high protein such as eggs dirutin for 5 days, warm ginger water drink; honey. Psychological Experience: the patient says shock, shock, denial with rapid reactiveresults. Sociological Experience: patients do activities by keeping a distance with people's homes, neighbors and communities and selfintropeksi about things experienced. Spiritual Experience: the patient says to perform worship at home.

\section{Conclusion}

The high positive rate of Covid-19 in Indonesia makes the emergence of stigma negatif massyrian to exposed patients, not even just Covid-19 positive patients who get negative stigma. It all happened because of excessive concern in the community. It is true to keep the distance to be served from Covid-19, bahow caraspread, and prevention. Sufferers with suspected Covid-19 (Rapid Reactive) are not to be shunned let alone ostracized, they need the support of the community spirit. Health counseling In this era of highly sophisticated technology, it is wise to give a message in the counseling by means of education. Education is one of the most powerful ways to stop stigma. There are many ways of education that can be done such as socialization through social media, giving leaflets to the public about how to transmit.

\section{References}

Dinas Kesehatan Pontianak, Maret 2020. Laporan Program Covid-19 Kabupaten Pontianak. Kalimantan Barat

Durrani, H \& Khoja. (2009). A systematic review of the use of telehealth in Asian countries. Journal of Telemedicine and Telecare 2009; 15: 175-181. Diakses melalui www.proquest.com tanggal 19 Maret 2017.

George et al. (2008). How safe is telenursing from home. Australian Journal of Advanced Nursing, Volume 26 Number 1:26-31. Diakses melalui www.proquest.com tanggal 19 Maret 2017

Hoglund et al. International Journal for Equity in Health (2016) DOI 10.1186/s12939-0160447-0, London

Kemenkes, Penanganan Cepat Medis dan Kesehatan Masyarakat Covid-19. Jakarta : Maret, 2020.

Keliat, Akemat, Helena, N, Nurhaeni, H (2012). Keperawatan Kesehatan Jiwa Komunitas : CMHN ( basic course), Jakarta : EGC

Muharyani, P.W. (2011). Aplikasi Short Message Service (SMS) Dalam Promosi Kesehatan Reproduksi di Komunitas. Tesis. Program Pasca Sarjana..Universitas Indonesia. Jakarta

Musyarofah Hanifah dkk, (2020). Kajian Kecemasan Masyarakat Cilacap dalam mengahadapi pandemic Covid 19. Respiratory UNUGHA.

Nawan Budi Yanti dkk, (2020). Community Knowledge, Attitudes, and Behavior Towards Social Distancing Policy as Prevention Transmission of Covid-19 in Indonesia. Jurnal Administrasi Kesehatan Indonesia. Hal 4-14.

Ningrum, P.A., Hukom, A., and Adiwijaya, S. (2020). The Potential of Poverty in the City of Palangka Raya: Study SMIs Affected Pandemic Covid 19. Budapest International Research and Critics Institute-Journal (BIRCI-Journal) Vol 3 (3): 1626-1634.

Scotia. (2008). Telenursing practice guideline. College of Registered Nurses of Nova Scotia. Diakses melalui www.proquest.com tanggal 19 Maret 2017.

Tribowo, (2013). Manajemen Pelayanan Keperawatan di Rumah Sakit, Jakarta. TIM

Wijaya, O.Y. (2021). Risk Management Mitigation in the New Normal Era. Budapest 
International Research and Critics Institute-Journal (BIRCI-Journal) Vol 4 (1): 10881097.

World Health Organization. (November, 2019 ) Global Covid-19 control: WHO report (WHO/HTM/TB/2019). Geneva 